\title{
In Vitro Antileukemic Activity of Formamidine Epidoxorubicin Analogs
}

\author{
LIDIA MAZUR ${ }^{1}$, MAŁGORZATA OPYDO-CHANEK ${ }^{1}$, KATARZYNA ŚLADOWSKA $^{1}$, BARBARA JANOTA ${ }^{1}$, \\ URSZULA KŁAPUT $^{1}$, MAŁGORZATA ŁUKAWSKA ${ }^{2}$ and IRENA OSZCZAPOWICZ ${ }^{2}$ \\ ${ }^{1}$ Department of Experimental Hematology, Institute of Zoology and Biomedical Research, \\ Jagiellonian University, Krakow, Poland; \\ ${ }^{2}$ Department of Modified Antibiotics, Institute of Biotechnology and Antibiotics, Warsaw, Poland
}

\begin{abstract}
Background/Aim: Epidoxorubicin is an anthracycline agent. The present study was undertaken to compare the antileukemic potential of epidoxorubicin and its two formamidine analogs containing either a morpholine moiety (EPIFmor) or a hexamethyleneimine moiety (EPIFhex) in the amidine group. Materials and Methods: The experiments were performed in vitro on MOLT-4 cells using spectrophotometry, Coulter electrical impedance, flow cytometry, and light microscopy methods. Results: The leukemia cell responses to the action of the anthracyclines were manifested in their different viability, count and volume, degree of apoptosis and necrosis, activity of caspases -8, -9, and -3/7, mitochondrial membrane potential, and in the cellcycle distribution. In general, epidoxorubicin appeared to be the most active, and EPIFmor was more active than EPIFhex against MOLT-4 cells. Conclusion: The structural modifications of epidoxorubicin in the amidine group were responsible for the varied action of its formamidine analogs on human acute lymphoblastic leukemia cells.
\end{abstract}

Anthracyclines are anticancer agents with broad clinical implications. Nevertheless, anthracycline compounds still have an improvable therapeutic index (1-3). The development of new analogs is one of the strategies for improving the efficacy of the parent anthracycline drugs used in chemotherapy. Structural modifications of currently approved anthracyclines are an important way to change their anticancer activity $(2,4)$.

Correspondence to: Lidia Mazur, Ph.D., D.Sc., Department of Experimental Hematology, Institute of Zoology and Biomedical Research, Jagiellonian University, Gronostajowa 9, 30-387 Krakow, Poland. Tel: +48 126645237, Fax: +48 126645101, e-mail: lidia.mazur@uj.edu.pl

Key Words: Formamidine epidoxorubicin analogs, human acute leukemia cells, cell viability, regulated cell death, cell cycle.
Epidoxorubicin (EPI) represents the second generation of anthracycline compounds. Epidoxorubicin is a semisynthetic derivative of doxorubicin obtained by an axial to equatorial epimerization of the hydroxyl group at C-4' in daunosamine $(1,2,4,5)$. In search for new derivatives of anthracycline agents, formamidine analogs of epidoxorubicin, containing either a morpholine moiety (EPIFmor) or a hexamethyleneimine moiety (EPIFhex) in the amidine group, were synthesized and their biological properties were tested under in vitro conditions on different cell lines (6-9). However, available information on anticancer potential of the synthesized formamidinoepidoxorubicins (7-9), and especially their antileukemic activity is still scant $(8,10)$.

Cell viability, size, and count $(11,12)$, cell death $(13,14)$, and the cell cycle (15) are important parameters for determining the antileukemic activity of potential anticancer agents. Induction of cell death and changes in the cell cycle by different chemical agents can affect the cell viability, size, and count $(13,16)$. The alterations in these parameters observed after application of tested compounds reflect their cytotoxic activity (11-16).

Regulated cell death plays a critical role in cellular response to the action of various factors $(17,18)$. Apoptosis and necrosis are accepted to be two principal modes of cell death $(19,20)$. During cell death induced by different cytotoxic agents, both functional and morphological changes occur $(19,21-23)$. There are two main pathways, the receptor/extrinsic and mitochondrial/intrinsic pathways, that play a pivotal role in cells undergoing apoptotic and necrotic death $(20,24,25)$. These two pathways lead to activation of caspases which are the important mediators of apoptotic cell death $(20,26)$. The initiator caspase- 8 and caspase- 9 are activated, respectively, through the receptor and mitochondrial pathways. These initiator caspases activate executor caspases $(21,27)$. It is accepted that mitochondria have a central role in cellular homeostasis being the major energy factory of cells (28), and apoptosis and necrosis are generally determined as being energy-dependent cell death 
types $(29,30)$. Mitochondrial dysfunction can be reflected in mitochondrial membrane permeability, the release of proapoptotic factors, the formation of the apoptosome, which activates caspase-9, and a decrease of mitochondrial membrane potential $(21,31,32)$. These changes in mitochondria, as well as alterations triggered in the nucleus and cell membrane by detrimental factors, can be involved not only in different manifestations of cell death (33-35), but also in cell-cycle perturbation $(21,32,36)$.

To our knowledge, there are no published data on the effects of epidoxorubicin derivatives, containing a morpholine ring or a hexamethyleneimine ring in the formamidine group, on human acute leukemia cells. Elucidating and comparing the modes of action of the parent anthracycline epidoxorubicin and its analogs on malignant hematopoietic cells require knowledge on their influence on the cell viability, regulated cell death and the cell cycle. Therefore, the aim of the present study was to assess the in vitro cytotoxic activity of epidoxorubicin and the two analogs EPIFmor and EPIFhex against human acute lymphoblastic leukemia cells. The influence of these three anthracycline agents on cell viability, count and size, apoptotic and necrotic cell death, and alterations in the cell cycle was analyzed. In order to determine the mechanisms of action of the tested anthracyclines, the changes in plasma membrane structure and integrity, caspase activation, mitochondrial membrane potential, and the cell-cycle phase distribution, were evaluated.

\section{Materials and Methods}

Chemicals. The anthracycline compounds, epidoxorubicin and its two formamidine derivatives EPIFmor and EPIFhex, were synthesized at the Institute of Biotechnology and Antibiotics (Warsaw, Poland). The formamidinoepidoxorubicin compounds were obtained in the reaction of epidoxorubicin hydrochloride with acetals, derivatives of $\mathrm{N}$-formylamines. The structure of the formamidinoepidoxorubicins were confirmed by their ${ }^{1} \mathrm{H}$ and ${ }^{13} \mathrm{C}$ nuclear magnetic resonance (NMR) spectra. Purity of all compounds was $\geq 98.5 \%$ according to the HPLC methods (6). The anthracycline agents, EPI, EPIFmor, and EPIFhex, were dissolved in aqua pro injectione (Polpharma, Starogard Gdański, Poland). Stock solutions of these three anthracycline agents, at a concentration of $0.5 \mathrm{mM}$, were stored in the dark at $-20^{\circ} \mathrm{C}$. All working solutions were freshly prepared directly before treatment of cells (Figure 1).

RPMI-1640 medium, fetal calf serum, and Hank's balanced salt solution (HBSS) were obtained from Gibco BRL Life Technologies (Waltham, MA, USA). L-glutamine, antibiotic antimycotic solution (AAS), 3-[4,5-dimethylthiazol-2-yl]-2,5-diphenyl tetrazolium bromide (MTT), tetramethylrhodamine ethyl ester perchlorate (TMRE), and dimethyl sulfoxide (DMSO) were purchased from Sigma Aldrich (St. Louis, MO, USA). Hydrochloric acid ( $\mathrm{HCl}$ ) and absolute isopropanol from Krakchemia S.A. (Kraków, Poland), formaldehyde from Polish Chemical Reagents, S.A. (Gliwice, Poland), ISOTON II (filtered electrolyte solution based on $0.9 \%$ saline) from Beckman Coulter Inc. (Brea, CA, USA), phosphatebuffered saline (PBS) from BioMed (Lublin, Poland), and
Hemacolor staining set from Merck KGaA (Darmstadt, Germany) were obtained. CaspGLOW Red Active Caspase-8 Staining Kit and CaspGLOW Red Active Caspase-9 Staining Kit from Biovision (Milpiats, CA, USA), and CellEvent ${ }^{\mathrm{TM}}$ Caspase-3/7 Green Flow Cytometry Assay Kit from Molecular Probes (Eugene, OR, USA), were purchased. Annexin V-FITC Apoptosis Detection Kit and propidium iodide (PI)/RNase staining buffer were obtained from Becton Dickinson Pharmingen ${ }^{\mathrm{TM}}$ (San Diego, CA, USA).

Leukemia cells. Human acute lymphoblastic leukemia MOLT-4 cells were obtained from the European Collection of Cell Cultures (Salisbury, Wiltshire, UK). MOLT-4 cells were cultured in RPMI-1640 medium supplemented with $10 \%$ fetal calf serum, $2 \mathrm{mM} \mathrm{L-glutamine,}$ and AAS containing 20 units of penicillin, $20 \mu \mathrm{g}$ streptomycin and 50 ng amphotericin B. Every third day, MOLT- 4 cells were passaged. The leukemia cells grew at $37^{\circ} \mathrm{C}$ in an atmosphere of $5 \% \mathrm{CO}_{2}$ in air (HERAcell incubator; KendroLab, Warsaw, Poland).

Leukemia cell treatment with anthracyclines. After a dilution of the cell suspension to a density of $15 \times 10^{4}$ cells $/ \mathrm{ml}$ of complete RPMI1640 medium, MOLT- 4 cells were treated with epidoxorubicin and its two formamidine analogs. The concentrations of the anthracyclines used in the experiments were based on the half maximal inhibitory concentration $\left(\mathrm{IC}_{50}\right)$ values determined using the in vitro MTT assay. The control consisted of untreated MOLT-4 cells. The analyses were performed on the leukemia cells at 24/48 $\mathrm{h}$ after anthracycline application.

In vitro spectrophotometric MTT assay. In order to determine the viability of MOLT-4 cells, an analysis of the optical density of formazan solution was performed, according to the protocol described in detail by Śladowska et al. (12). The $\mathrm{IC}_{50}$ value for each anthracycline was determined separately in MOLT- 4 cells at the concentration range of EPI and EPIFmor from 10-100 nM, and EPIFhex from 20-500 $\mathrm{nM}$.

Cell sizing and counting - Coulter method. The leukemia cell volume and count were analyzed as previously described by Śladowska et al. (12). After the dilution of cell suspension in ISOTON II (1:9), the count and volume of MOLT-4 cells were determined to be in the range of 495-3622 $\mathrm{fl}$.

Flow cytometric analysis of apoptotic and necrotic leukemia cells. The cell surface exposure of phosphatidylserine and plasma membrane impairment were assessed by dual staining of MOLT- 4 cells with annexin V-FITC and PI, using Annexin V-FITC Apoptosis Detection Kit. Briefly, leukemia cell suspension containing approximately $5 \times 10^{5}$ cells was centrifuged for $7 \mathrm{~min}$ at $100 \times g$ and $4^{\circ} \mathrm{C}$ (MPW-351RH centrifuge; Med. Instruments, Warszawa, Poland). Next, the cells were washed with cold PBS. After centrifugation of the cell suspension, the supernatant was removed, and the cells were resuspended in $100 \mu \mathrm{l}$ of cold binding buffer. Then $2.5 \mu \mathrm{l}$ of annexin V-FITC and $2.5 \mu \mathrm{l}$ of PI were added and the cells were incubated in the dark for $15 \mathrm{~min}$ at room temperature. Following incubation, $400 \mu \mathrm{l}$ of cold binding buffer was added. Cell samples were placed on ice, away from light, and FITC and PI fluorescence was immediately measured, using a flow cytometer (Becton Dickinson, San Jose, CA, USA).

Microscopic analysis of leukemia cell morphology. In order to prepare cytospins, leukemia cell suspension, eventually diluted in PBS, 
<smiles>COc1cccc2c1C(=O)c1c(O)c3c(c(O)c1C2=O)C[C@@](O)(C(=O)CO)C[C@@H]3OC1CC(N)C(C)(O)C(C)O1</smiles>

EPI<smiles>COc1cccc2c1C(=O)c1c(O)c3c(c(O)c1C2=O)C[C@@](O)(C(=O)CO)C[C@@H]3OC1OC2C(C)C(O)N=CC(N3CCOCC3)C2C1C</smiles>

EPIFmor

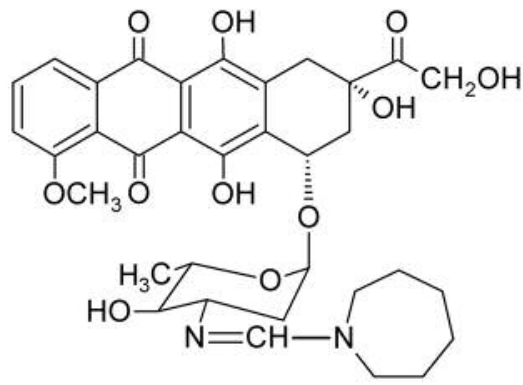

EPIFhex

Figure 1. Chemical structures of epidoxorubicin (EPI) and its formamidine derivatives containing either a morpholine moiety (EPIFmor) or a hexamethyleneimine moiety (EPIFhex) in the amidine group.

containing approximately $2 \times 10^{5}$ cells, was placed into a cytospin chamber and centrifuged for $6 \mathrm{~min}$ at $100 \times g$ and $4^{\circ} \mathrm{C}$ (MPW-350R centrifuge; Med. Instruments, Warszawa, Poland). After air drying, the prepared cytospins were fixed in methanol at room temperature for $15 \mathrm{~min}$. Immediately before staining, the cytospins with the fixed cells were rinsed with PBS, and stained with the Hemacolor staining set. The stained cytospins were examined using a light microscope (PrimoStar; Carl Zeiss, Poznań, Poland). Morphological analysis of apoptotic and necrotic MOLT-4 cells was performed. The incidence of cells with apoptotic and necrotic features among 9,000 MOLT -4 cells $(1,000$ cells per slide $\times 3$ slides $)$ was determined.

Flow cytometric analysis of caspase- 8 and -9 activities. The leukemia MOLT- 4 cells with active caspase- 8 and caspase- 9 were analyzed using, respectively, CaspGLOW Red Active Caspase- 8 Staining Kit and CaspGLOW Red Active Caspase-9 Staining Kit. Briefly, the cell suspension was centrifuged for $7 \mathrm{~min}$ at $100 \times g$ and $37^{\circ} \mathrm{C}$ (MPW-351RH; Med. Instruments), and the supernatant was removed by aspiration. The cell pellet was resuspended in 150 $\mu \mathrm{l}$ of PBS, and $0.5 \mu \mathrm{l}$ of Red-IETD-fluoromethylketone or $0.5 \mu \mathrm{l}$ of Red-LEHD-fluoromethylketone was added into each sample, and the cells were incubated for $1 \mathrm{~h}$ at $37^{\circ} \mathrm{C}$. Then the cells were centrifuged, the supernatant was removed, and the cells were washed twice in $500 \mu \mathrm{l}$ of wash buffer. After the washing step, the cells were resuspended in $300 \mu \mathrm{l}$ of wash buffer and immediately analyzed by flow cytometry (Becton Dickinson).

Flow cytometric analysis of caspase-3/7 activity. Activity of caspase-3/7 in leukemia MOLT-4 cells were analyzed using CellEvent ${ }^{\mathrm{TM}}$ Caspase-3/7 Green Flow Cytometry Assay Kit. Briefly, the cell suspension was centrifuged for $7 \mathrm{~min}$ at $100 \times g$ and $37^{\circ} \mathrm{C}$ (MPW $351 \mathrm{RH}$; Med. Instruments) and the supernatant was removed by aspiration. The cells were resuspended in $500 \mu \mathrm{l}$ of PBS. Then $0.5 \mu \mathrm{l}$ of CellEvent ${ }^{\mathrm{TM}}$ Caspase-3/7 Green Detection reagent was added to each sample and the cells were incubated for $30 \mathrm{~min}$ at $37^{\circ} \mathrm{C}$. After incubation, the leukemia cell samples were immediately analyzed using flow cytometry (Becton Dickinson).

Flow cytometric analysis of mitochondrial membrane potential $(M M P)$. TMRE assay was used to analyze the MMP. A TMRE stock solution was prepared at a concentration of $10 \mathrm{mM}$ in DMSO and stored at $-20^{\circ} \mathrm{C}$. The final concentration of TMRE staining solution used was $100 \mathrm{nM}$. The leukemia cell suspensions, containing approximately $2.5-5 \times 10^{5} \mathrm{cells} / \mathrm{ml}$, were centrifuged for $7 \mathrm{~min}$ at $100 \times \mathrm{g}$ and $37^{\circ} \mathrm{C}$ (MPW-351RH; Med. Instruments). Then the cell pellet was washed twice in $1 \mathrm{ml}$ of warm HBSS. Next, the cells were resuspended in $100 \mu \mathrm{l}$ of $100 \mathrm{nM}$ TMRE, and incubated at $37^{\circ} \mathrm{C}$ in the darkness. After 20-min incubation, the cells were washed with $1 \mathrm{ml}$ of warm HBSS and centrifuged. Finally, the supernatant was discarded, the cells were resuspended in $500 \mu \mathrm{l}$ of HBSS, and TMRE fluorescence was immediately detected by flow cytometry (Becton Dickinson).

Flow cytometric analysis of the cell cycle. Using PI/RNase staining buffer, the cell cycle distribution was analyzed. The leukemia cell suspension was centrifuged for $7 \mathrm{~min}$ at $100 \times \mathrm{g}$ and $4^{\circ} \mathrm{C}$ (MPW$351 \mathrm{RH}$ centrifuge; Med. Instruments) and the supernatant was discarded. The cells were washed in $2 \mathrm{ml}$ of cold PBS. The supernatant was removed, the cell pellet was resuspended in $500 \mu \mathrm{l}$ of PBS, and $4.5 \mathrm{ml}$ of $70 \%$ of ice-cold ethanol was added to the sample. The cells were fixed in a refrigerator for $60 \mathrm{~min}$, and then stored at $-20^{\circ} \mathrm{C}$ before use. Before staining with PI, the leukemia cell suspension was centrifuged, and the cell pellet was resuspended in $1 \mathrm{ml}$ of wash buffer. The cells were then centrifuged, the supernatant was removed, and the cell pellet was resuspended in $300 \mu \mathrm{l}$ of PI/RNase staining buffer. Next, the cells were incubated in the darkness for $30 \mathrm{~min}$ at room temperature. After the incubation, PI fluorescence was detected using flow cytometry (Becton Dickinson).

Statistical evaluation. The flow cytometric data were analyzed using CellQuest Pro software (Becton Dickinson). All the data are presented as the mean values \pm standard deviation, calculated from three or four independent experiments carried out in triplicate or duplicate. Statistical analyses were performed using STATISTICA 10 (StatSoft, Krakow, Poland). Data were analyzed by one-way analysis of variance (ANOVA) followed by Tukey's honestly significant differences (HSD) multiple range test. A difference with $p<0.05$ was considered statistically significant. 
Table I. The optical density of formazan solution and viability of MOLT-4 cells determined 48 h after their exposure to the action of epidoxorubicin (EPI) and its formamidine derivatives, EPIFmor and EPIFhex, using the spectrophotometric 3-[4,5-dimethylthiazol-2-yl]-2,5-diphenyl tetrazolium bromide (MTT) assay. The extent of MTT conversion to formazan by leukemia cells expressed as a percentage of the control value reflects their viability.

\begin{tabular}{|c|c|c|c|c|c|c|}
\hline \multirow[b]{2}{*}{ Concentration (nM) } & \multicolumn{3}{|c|}{ Optical density of formazan solution $\left(\times 10^{-2}\right)$} & \multicolumn{3}{|c|}{ Cell viability (\%) } \\
\hline & EPI & EPIFmor & EPIFhex & EPI & EPIFmor & EPIFhex \\
\hline 10 & $12.6 \pm 0.3$ & $13.5 \pm 0.2$ & - & $86.3 \pm 2.0$ & $92.5 \pm 1.4$ & - \\
\hline 20 & $9.5 \pm 0.3$ & $12.8 \pm 0.2$ & $14.2 \pm 0.2$ & $65.1 \pm 2.0$ & $87.7 \pm 1.4$ & $97.3 \pm 1.4$ \\
\hline 30 & $7.2 \pm 0.8$ & $11.3 \pm 0.3$ & - & $49.3 \pm 5.5$ & $77.4 \pm 2.1$ & - \\
\hline 40 & $1.8 \pm 0.1$ & - & - & $12.3 \pm 0.7$ & - & - \\
\hline $\mathbf{5 0}$ & $1.5 \pm 0.3$ & $7.3 \pm 0.9$ & $13.2 \pm 0.7$ & $10.3 \pm 2.1$ & $50.0 \pm 6.2$ & $90.4 \pm 4.5$ \\
\hline 70 & - & $5.1 \pm 0.2$ & - & - & $34.9 \pm 1.4$ & - \\
\hline 80 & - & $3.4 \pm 0.8$ & - & - & $23.3 \pm 5.5$ & - \\
\hline 100 & $1.1 \pm 0.2$ & $2.5 \pm 0.3$ & $11.8 \pm 1.5$ & $7.5 \pm 1.4$ & $17.1 \pm 2.1$ & $80.8 \pm 10.3$ \\
\hline 200 & - & - & $7.4 \pm 0.5$ & - & - & $50.7 \pm 3.4$ \\
\hline 300 & - & - & $3.6 \pm 0.2$ & - & - & $24.6 \pm 1.4$ \\
\hline 500 & - & - & $1.8 \pm 0.3$ & - & - & $12.3 \pm 2.1$ \\
\hline
\end{tabular}

Control

$14.6 \pm 0.9$

- Not done. Bold data correspond to the concentrations equal or similar to the half-maximal inhibitory concentration $\left(\mathrm{IC}_{50}\right)$ values. The $\mathrm{IC}_{50} \mathrm{value}$ for EPIFmor was determined as $50 \mathrm{nM}$.

A

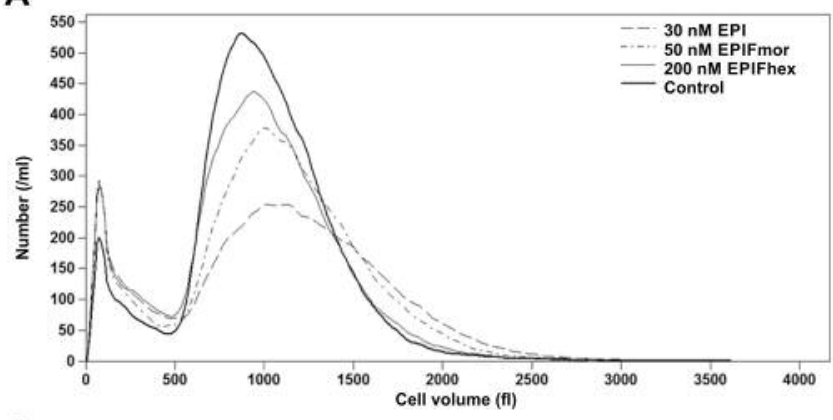

C

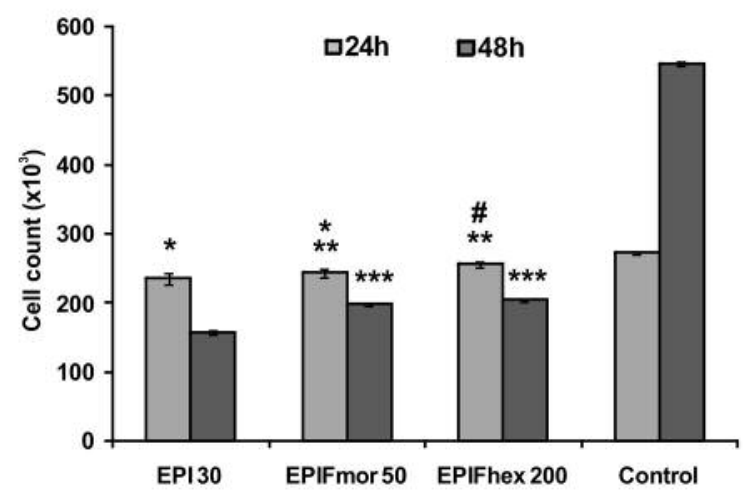

B

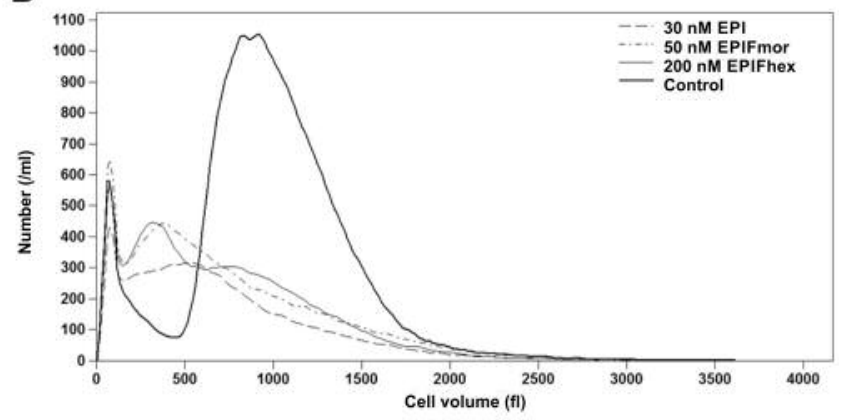

D

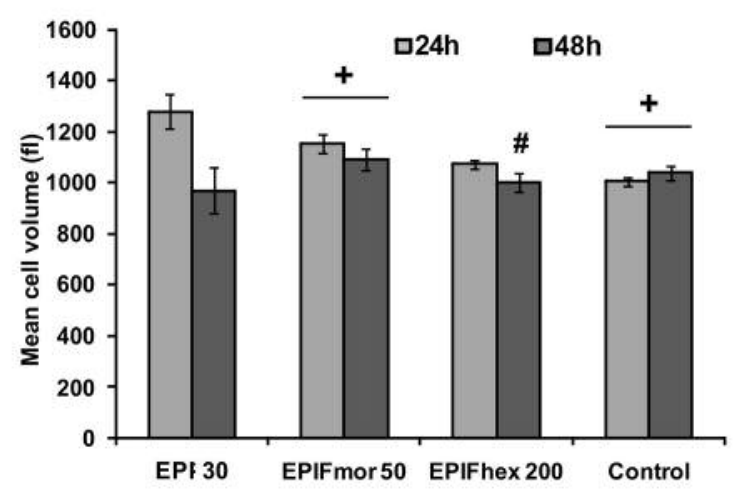

Figure 2. Effects of epidoxorubicin (EPI), EPIFmor, and EPIFhex on the count and volume of MOLT-4 cells. The volume distribution curves of the leukemia cells were recorded $24(A)$ and $48 h(B)$ after their exposure to the action of the tested anthracyclines using a Z2 Coulter counter. The peaks on the left represent cellular debris, presumably apoptotic bodies and cell fragments, which were excluded from the analysis of the MOLT-4 cell volume. The cell count $(C)$ and the mean cell volume $(D)$ were determined 24 and 48 h after application of EPI, EPIFmor, and EPIFhex, at concentrations equal to or approximately the half-maximal inhibitory concentration values, calculated for each anthracycline agent, respectively, as $30 \mathrm{nM}$ (EPI30), $50 \mathrm{nM}$ (EPIFmor50), and $200 \mathrm{nM}$ (EPIFhex200). Values not significantly different at $p<0.05$ according to Tukey's multiple range test: ${ }^{\#}$ compared to control; *, **, ***between groups of leukemia cells treated with anthracyclines; ${ }^{+}$between time points. 

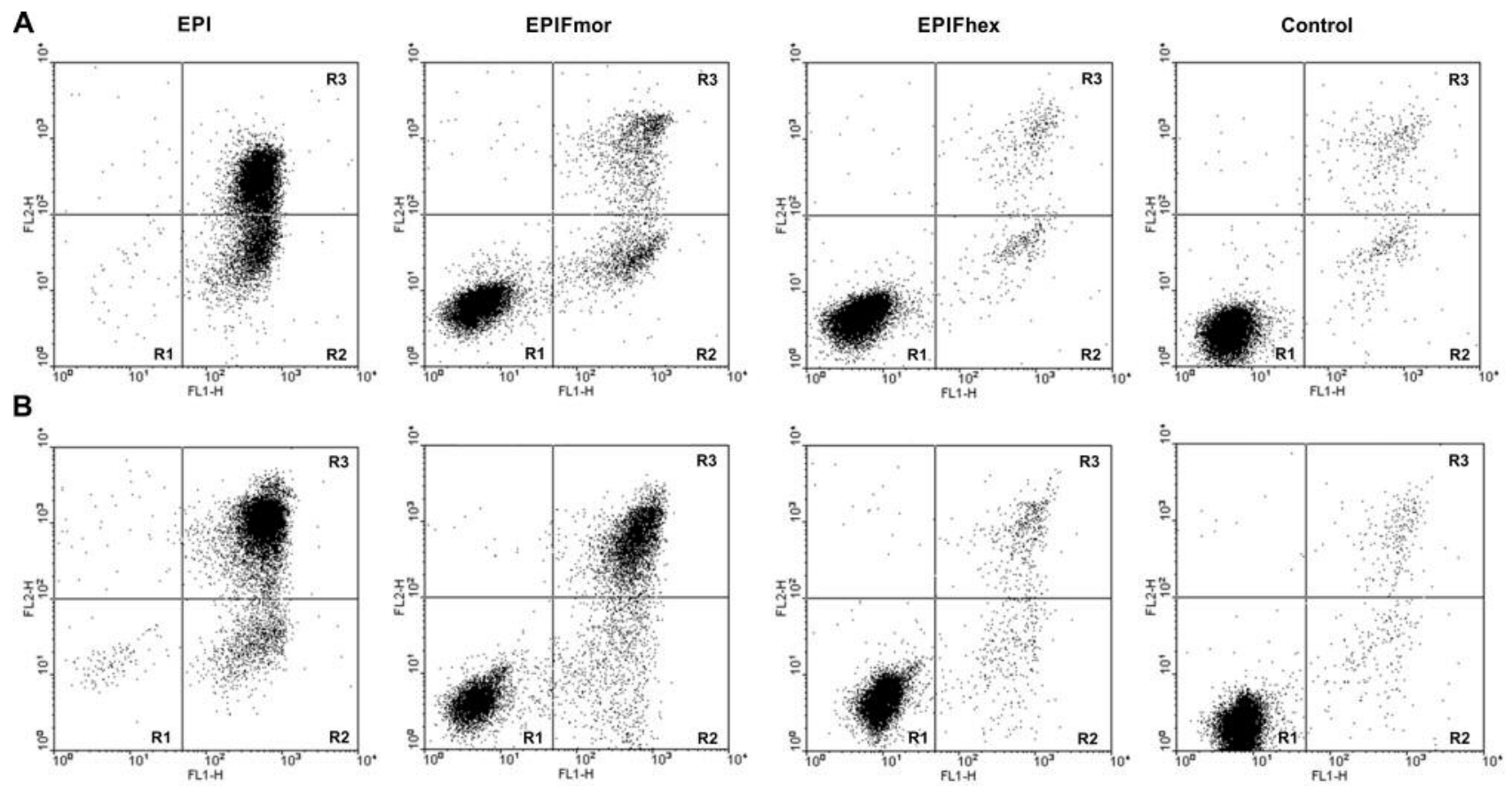

C

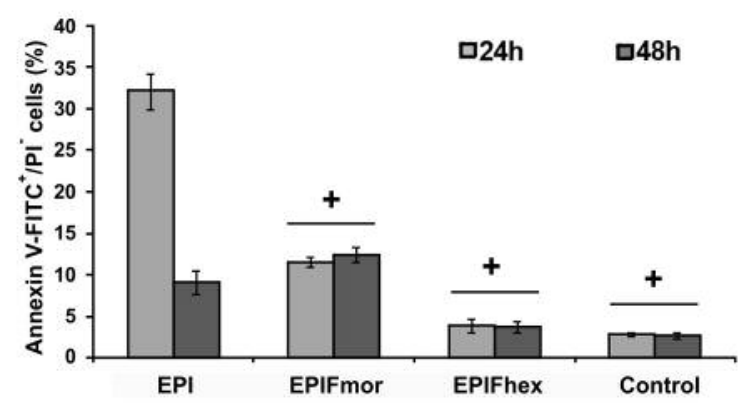

D

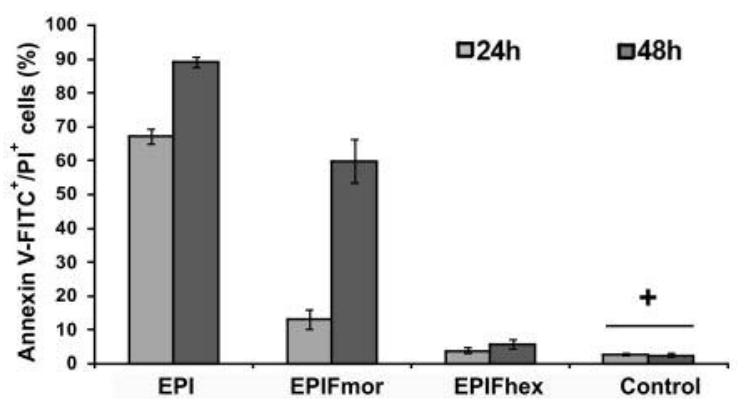

Figure 3. Effects of epidoxorubicin (EPI), EPIFmor, and EPIFhex, applied at $50 \mathrm{nM}$, on the plasma membrane structure and integrity of MOLT-4 cells. Representative dot plots of MOLT-4 cells obtained $24 \mathrm{~h}(\mathrm{~A})$ and $48 \mathrm{~h}(\mathrm{~B})$ after application of the anthracyclines, using flow cytometry fluorescein-conjugated annexin V (annexin V-FITC)/propidium iodide (PI) assay; FL1-H: green fluorescence of FITC, FL2-H: red fluorescence of PI; R1: live cells (annexin V-FITC-/PI-) R2: early apoptotic cells (annexin V-FITC ${ }^{+} / P I^{-}$); R3: late apoptotic and necrotic cells (annexin V$\left.F_{T T C} / P^{+}\right)$. The frequency of early apoptotic $(C)$ and late apoptotic and necrotic $(D)$ MOLT-4 cells was determined 24 and 48 h after their exposure to the action of the tested anthracyclines. ${ }^{+}$Values not significantly different between time points at $p<0.05$ according to Tukey's multiple range test.

\section{Results}

The results of the present study demonstrated that epidoxorubicin and its formamidine analogs reduced MOLT-4 cell viability. Based on the optical density of formazan solution obtained $48 \mathrm{~h}$ after application of the anthracyclines (Table I), the $\mathrm{IC}_{50}$ values for EPI, EPIFmor, and EPIFhex were determined from the dose-response curves, as $30.4 \mathrm{nM}, 50.0$ $\mathrm{nM}$, and $197.3 \mathrm{nM}$, respectively. The anthracyclines, applied at the concentrations similar or equal to the $\mathrm{IC}_{50}$ values, influenced the count (Figure 2A-C) and volume (Figure 2A, B, and D) of MOLT- 4 cells to different extents. The exposure of leukemia cells to the action of the anthracycline agents, at the concentration of $50 \mathrm{nM}$, differently affected the frequency of both annexin $\mathrm{V}-\mathrm{FITC}^{+} / \mathrm{PI}^{-}$cells (Figure $3 \mathrm{~A}-\mathrm{C}$ ) and annexin $\mathrm{V}$ $\mathrm{FITC}^{+} / \mathrm{PI}^{+}$cells (Figure $3 \mathrm{~A}, \mathrm{~B}$, and D), cell morphology (Figure 4A), the apoptotic (Figure 4B) and necrotic (Figure 4C) index, the frequency of cells with active caspase- 8 (Figure $5 \mathrm{~B}$ ), -9 (Figure 5C), and -3/7 (Figure 5A and D), the percentage of cells with high MMP (Figure 6A and B), the distribution of the cell-cycle phases and sub- $\mathrm{G}_{1}$ population (Figure $7 \mathrm{~A}$ and $\mathrm{B}$ ), excluding the influence of EPIFhex on caspase-8 activation 

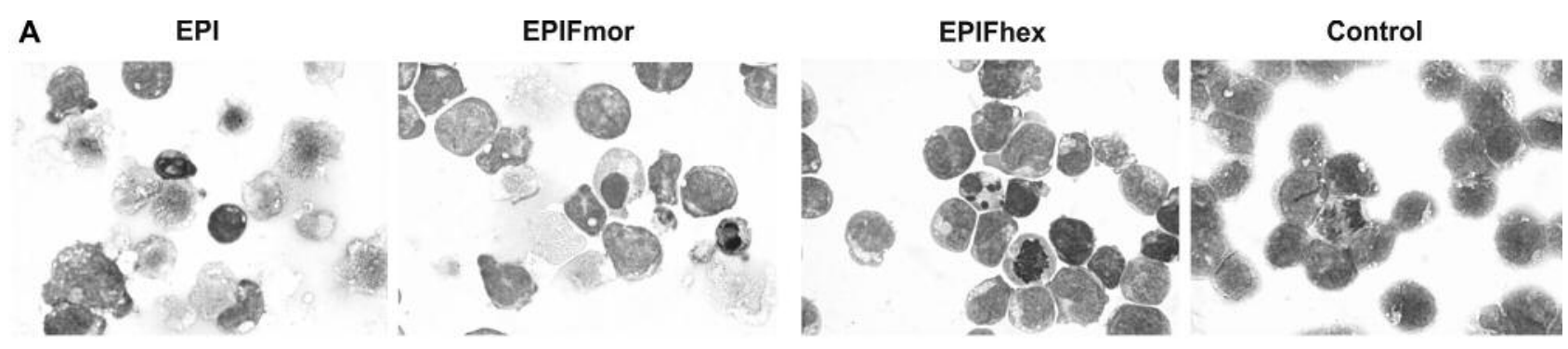

B

c
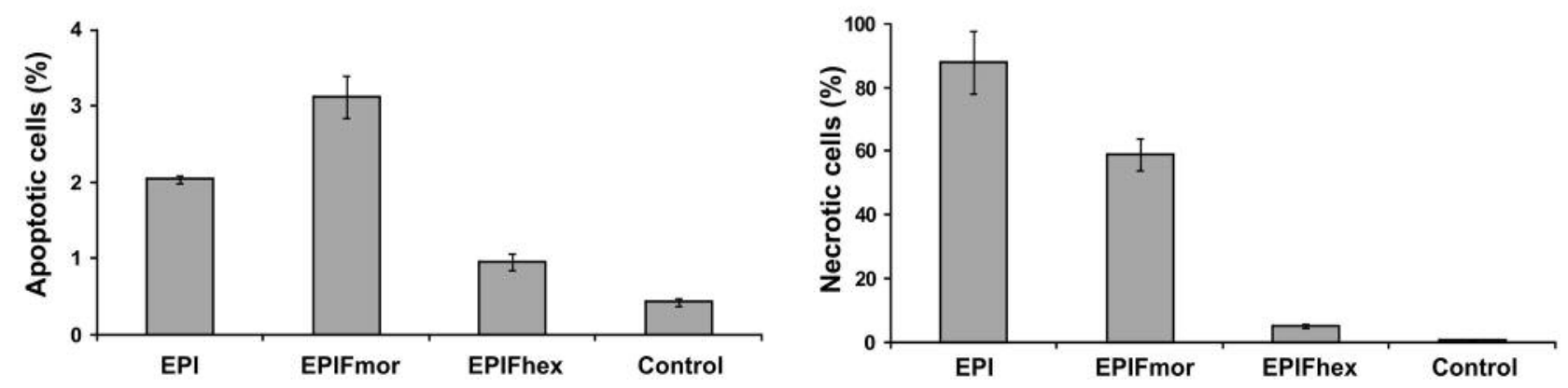

Figure 4. Morphological analysis of MOLT-4 cells undergoing apoptotic and necrotic cell death was performed 48 h after application of epidoxorubicin (EPI), EPIFmor, and EPIFhex, at $50 \mathrm{nM}$. A: Representative micrographs of MOLT-4 cells stained with the Hemacolor staining set, and observed under a light microscope; original magnification $\times 1,000$. Swollen necrotic cells, exhibiting morphological disintegration and membrane rupture are visible after application of EPI and EPIFmor, and one shrunk apoptotic cell with nuclear fragmentation is visible after the exposure of MOLT-4 cells to EPIFhex. After application of the tested anthracyclines, the frequency of apoptotic (B) and necrotic (C) cells was determined. All values differed significantly at $p<0.05$ according to Tukey's multiple range test.

A

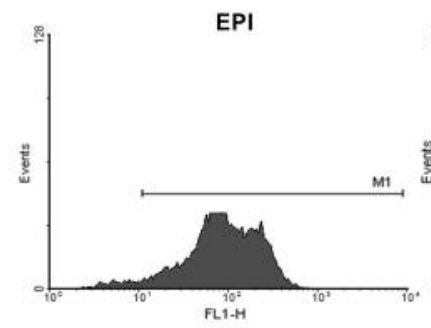

B

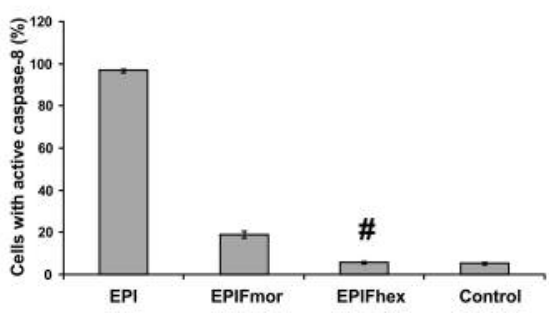

EPIFmor

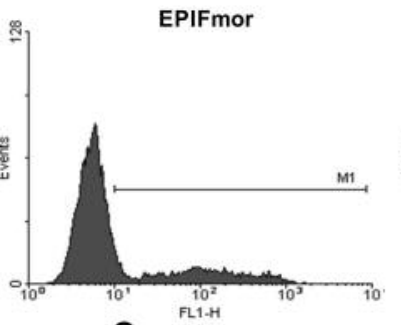

C

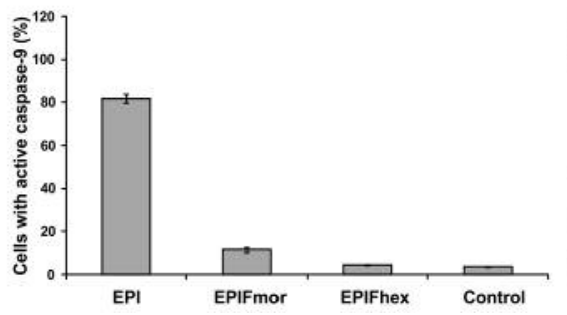

EPIFhex
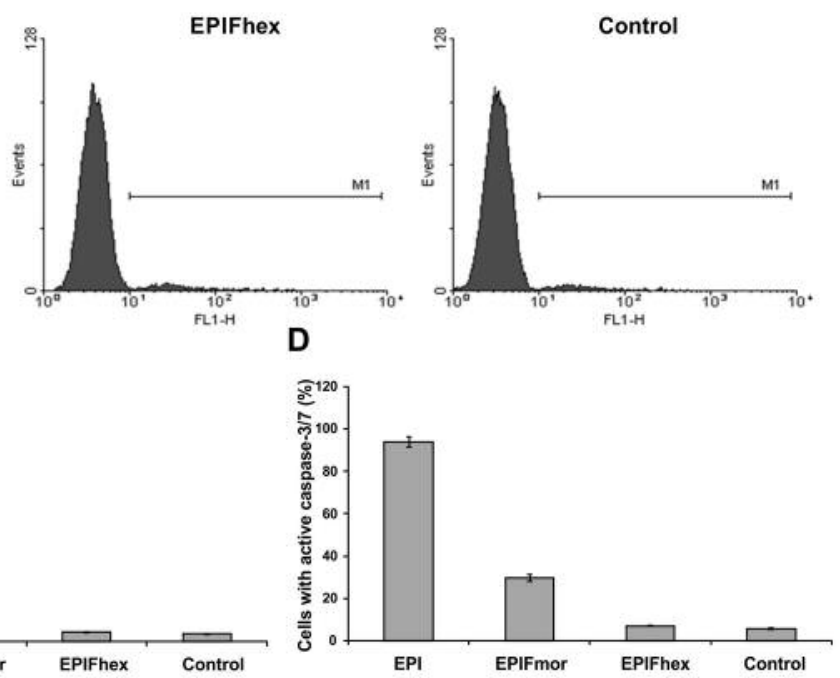

Figure 5. Flow cytometric analysis of MOLT-4 cells with active caspase-8, -9, and -3/7, conducted 24 h after application of epidoxorubicin (EPI), and its two formamidine analogs, EPIFmor and EPIFhex, at $50 \mathrm{nM}$. A: Representative histograms of MOLT-4 cells with active caspase-3/7; M1: Cells with active caspase-3/7; FL1-H: CellEvent ${ }^{T M}$ Caspase-3/7 Green fluorescence. The frequency of MOLT-4 cells with active caspase-8 (B), caspase-9 $(C)$, and caspase-3/7 (D) was determined after application of the tested anthracycline agents. "Values not significantly different compared to controls at $p<0.05$ according to Tukey's multiple range test. 
(Figure 5B), MMP dissipation (Figure 6A and B), and the cell cycle (Figure 7A and B). Thus, it can generally be stated that among the three anthracyclines, epidoxorubicin had the strongest activity and EPIFhex had the weakest activity against human leukemia MOLT-4 cells.

\section{Discussion}

The in vitro cytotoxic effects of epidoxorubicin and its two formamidine derivatives, EPIFmor and EPIFhex, on human acute lymphoblastic leukemia MOLT-4 cells were compared. After application of these anthracyclines, MOLT-4 cells exhibited different patterns of changes in their viability, count and volume, extent of apoptotic and necrotic death, phosphatidylserine externalization and plasma membrane integrity, activity of caspases- $8,-9$, and $-3 / 7$, mitochondrial membrane potential, and the cell cycle. Based on the $\mathrm{IC}_{50}$ values determined for EPI, EPIFmor and EPIFhex, the mode of action of each of these anthracyclines resulted in different viability of MOLT-4 cells. It can be accepted that the disorders of regulated cell death and cell-cycle disruption reflect leukemia cell viability. Moreover, the alterations observed in the leukemia cell count and volume surely resulted from the induction of cell death and cell-cycle disturbance by epidoxorubicin and its analogs.

The results of the present study indicate that the cytotoxic activities of two formamidinoepidoxorubicins, EPIFmor and EPIFhex, were weaker than that of the parental epidoxorubicin. Moreover, among these analogs of epidoxorubicin, EPIFmor, containing a morpholine moiety appeared to be more active against MOLT-4 cells than EPIFhex, containing a hexamethyleneimine moiety in the amidine group. Therefore, the transformation of the amino group at position 3 ' of the daunosamine moiety into a formamidine group $(-\mathrm{N}=\mathrm{CH}-\mathrm{N}<)$ resulted in analogs with different cytotoxic action compared to that of epidoxorubicin. EPIFmor and EPIFhex differ in the size of the cyclic amine ring in the amidine group (6). EPIFmor contains a six-membered morpholine ring with an oxygen heteroatom, while EPIFhex has a seven-membered hexamethyleneimine ring with a $\mathrm{CH}_{2}$ group in the $\gamma$-position in the formamidine group. The differences in the molecular structure of these two formamidine derivatives of epidoxorubicin appeared to be responsible for their different biological action on human acute lymphoblastic leukemia cells

The present study provides new insight into the mechanisms of cytotoxic action of epidoxorubicin and its formamidine analogs towards MOLT-4 cells. It was found that epidoxorubicin and the formamidinoepidoxorubicins, when applied at the same concentration of $50 \mathrm{nM}$, caused plasma membrane impairment and loss of its phospholipid asymmetry by phosphatidylserine externalization, nuclear damage and mitochondrial dysfunction, and promoted the activation of caspases through the mitochondrial pathway of
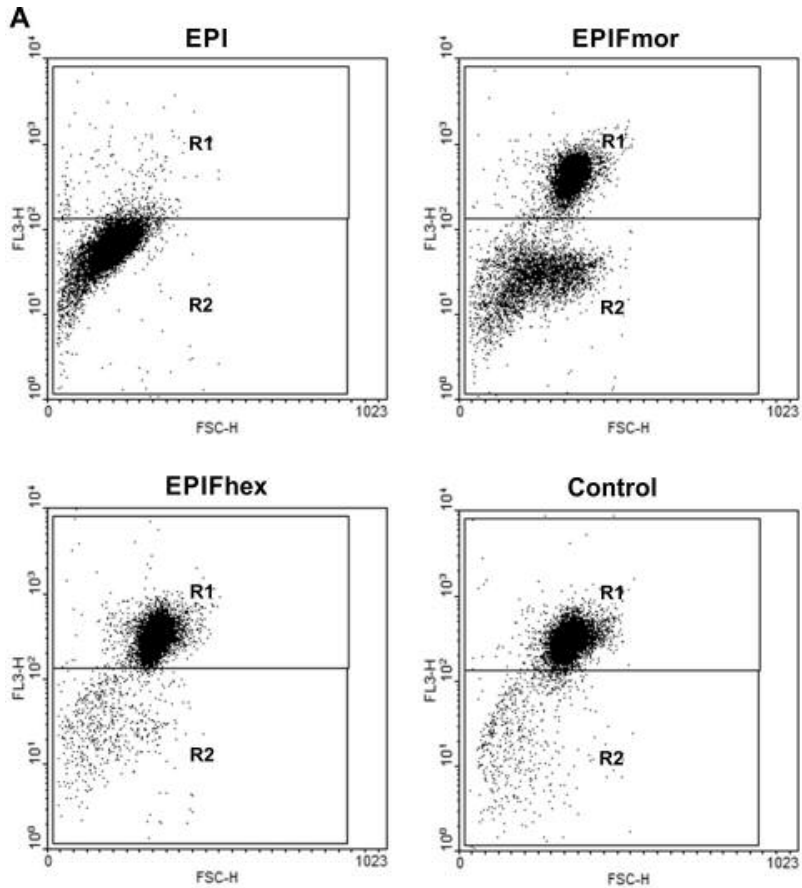

B

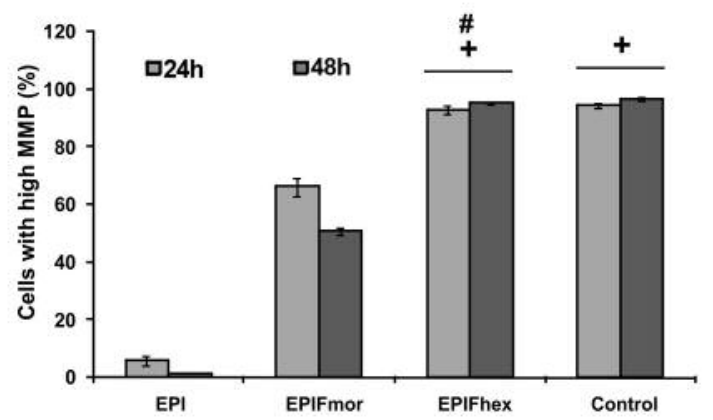

Figure 6. Effects of epidoxorubicin (EPI) and its formamidine derivatives, EPIFmor and EPIFhex, applied at $50 \mathrm{nM}$, on mitochondrial membrane potential (MMP) of MOLT-4 cells. A: Representative dot plots of MOLT-4 cells obtained $24 \mathrm{~h}$ after their exposure to the action of three anthracyclines, using flow cytometric tetramethylrhodamine ethyl ester test; R1: cells with high MMP, R2: cells with low MMP. B: The frequency of MOLT-4 cells with high MMP was determined $24 \mathrm{~h}$ and $48 \mathrm{~h}$ after application of the tested anthracycline agents. Values not significantly different at $p<0.05$ according to Tukey's multiple range test: ${ }^{\#}$ compared to controls; ${ }^{+}$between time points.

apoptotic death. However, only epidoxorubicin and EPIFmor reduced MMP, activated caspases through the receptor pathway, and affected the cell-cycle phase distribution in MOLT-4 cells. In the present study, the different mechanisms of action of epidoxorubicin, EPIFmor, and EPIFhex on human leukemia MOLT-4 cells, which include triggering apoptotic and necrotic death and causing the cell-cycle perturbation, were shown. 

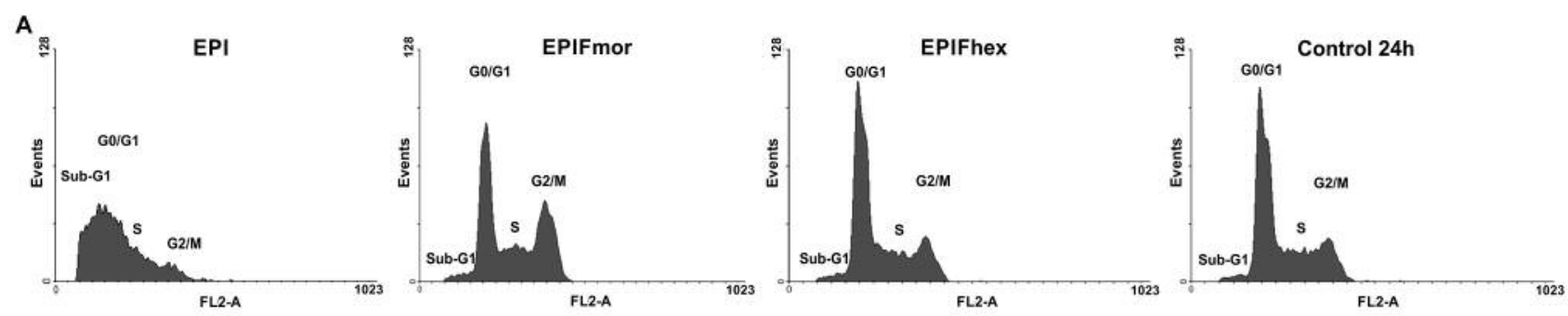

B

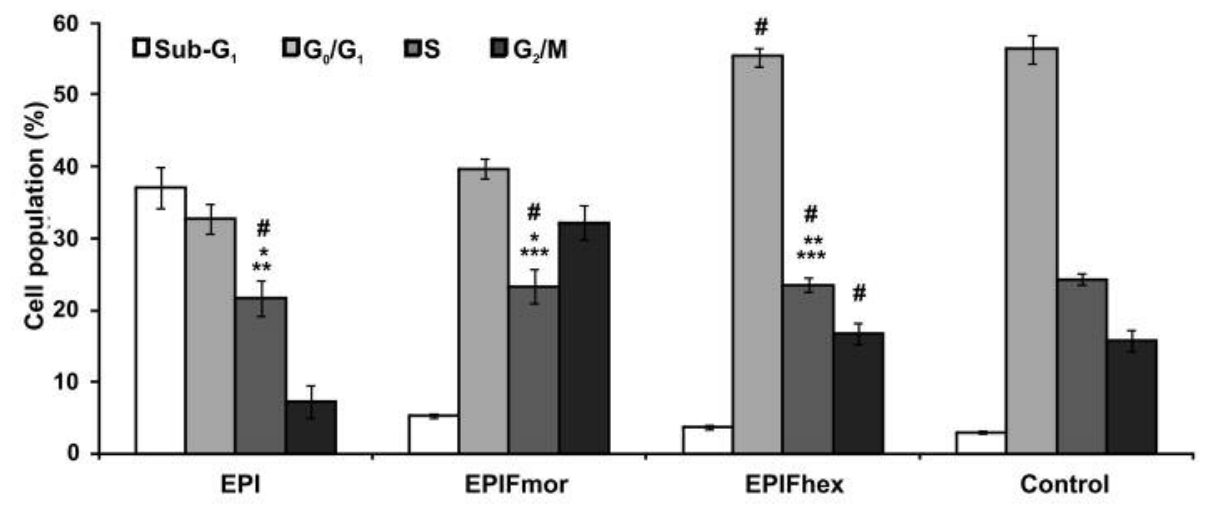

Figure 7. Effects of epidoxorubicin (EPI) and its formamidine derivatives, EPIFmor and EPIFhex, applied at 50 nM, on the cell cycle. A: Representative cell cycle histograms obtained $24 \mathrm{~h}$ after the exposure of MOLT-4 cells to the action of these anthracyclines, using flow cytometric analysis; FL2-A: propidium iodide fluorescence. Based on the content of cellular DNA staining with PI, four populations were distinguished, namely, $G_{I} / G_{0^{-}}, S$-, and $G_{2} / M$-phase cells, and sub- $G_{I}$ population. B: Quantitative changes in the sub- $G_{1}$ population and cell-cycle phase distribution were observed $24 \mathrm{~h}$ after exposure of MOLT-4 cells to the tested anthracyclines. Values not significantly different at $p<0.05$ according to the Tukey's multiple range test: " compared to controls; *, **, ***between the groups of leukemia cells treated with EPI, EPIFmor, and EPIFhex.

Multiple mechanisms have been proposed to explain the cytotoxic actions of anthracyclines $(2,4,37)$. It is known that epidoxorubicin generates free radicals with consequent interference with DNA, RNA, and proteins. Epidoxorubicin acts by intercalating of DNA strands, triggering DNA cleavage by topoisomerase II, which result in the inhibition of DNA and RNA synthesis $(2,4)$. Nevertheless, the modes of biological action of anthracyclines, including EPI, and especially their formamidine analogs, and the precise mechanisms responsible for the in vitro cytotoxic effects caused by these agents are not yet completely explained $(2,4,37)$.

\section{Conclusion}

The findings of the present study indicate that differences in the in vitro antileukemic activities of epidoxorubicin and its formamidine derivatives depend on their chemical structures. The structural modifications of the daunosamine moiety of epidoxorubicin were reflected in the varied responses of human acute lymphoblastic leukemia MOLT-4 cells to the triggering apoptotic and necrotic death and the cell-cycle disturbance by EPIFmor and EPIFhex. Understanding the mechanisms of action of formamidinoepidoxorubicin agents is essential for the development of novel therapeutic strategies. The relationship between the induction of regulated cell death and cell-cycle inhibition, and the efficacy of chemotherapy is still an open issue.

\section{Conflicts of Interest}

The Authors declare that there are no conflicts of interest.

\section{Acknowledgements}

Supported by Research Projects K/ZDS/004199 and K/ZDS/004835.

\section{References}

1 Hortobagyi GN: Anthracyclines in the treatment of cancer. An overview. Drugs 54: 1-7, 1997.

2 Minotti G, Menna P, Salvatorelli E, Cairo G and Gianni L: Anthracyclines: molecular advances and pharmacologic developments in antitumor activity and cardiotoxicity. Pharmacol Rev 56: 185-229, 2004.

3 Nadas J and Sun D: Anthracyclines as effective anticancer agents. Expert Opin Drug Discov 1: 539-548, 2006.

4 Mazur L and Opydo-Chanek M: Anthracyclines in Cancer Therapy: Past, Present Status and Future Prospects. In: Frontiers 
in Anti-Cancer Drug Discovery. Atta-ur-Rahman and Iqbal Choudhary M (eds.). Bentham Science Publishers, Vol. 6, Chapter 4, pp. 110-136, 2015.

5 Robert J: Epirubicin: clinical pharmacology and dose-effect relationship. Drugs 45: 20-30, 1993.

6 Oszczapowicz I, Wąsowska M, Oszczapowicz J, Owoc A, Dominiczak E, Wietrzyk J and Opolski A: New derivatives of anthracycline antibiotics, method and their synthesis, pharmaceutical agents containing them, and their use. Polish Patent 210494, 2005 (in Polish).

7 Wasowska M, Oszczapowicz I, Wietrzyk J, Opolski A, Madej J, Dzimira S and Oszczapowicz J: Influence of the structure of new anthracycline antibiotics and their biological properties. Anticancer Res 25: 2043-2048, 2005.

8 Wasowska M, Wietrzyk J, Opolski A, Oszczapowicz I and Oszczapowicz J: In vivo activity of new derivatives of anthracycline antibiotics. In: Ettmayer P and Ecker G (eds.), Joint Meeting of Medicinal Chemistry, Medimont, Vienna, pp. 81-85, 2005

9 Wasowska M, Wietrzyk J, Opolski A, Oszczapowicz J and Oszczapowicz I: Effect of structural modifications of anthracyclines on the ability to overcome drug resistance of cancer cells. Anticancer Res 26: 2009-2012, 2006.

10 Czyż M, Szuławska A, Bednarek AK, Düchler M: Effects of anthracycline derivatives on human leukemia K562 cell growth and differentiation. Biochem Pharmacol 70: 1431-1442, 2005.

11 Opydo-Chanek $\mathrm{M}$ and Mazur L: Comparison of in vitro antileukemic activity of obatoclax and ABT-737. Tumor Biol 37: 10839-10849, 2016.

12 Śladowska K, Handzlik J, Kieć-Kononowicz K and Mazur L: In vitro cytotoxic activity evaluation of phenytoin derivatives against human leukemia cells. Ind J Exp Biol 54: 553-559, 2016.

13 Opydo-Chanek M, Mazur L and Stojak M: In vitro cytotoxicity testing of new generation oxazaphosphorines against human histiocytic lymphoma cells. Ind J Exp Biol 51: 615-622, 2013.

14 Stojak M, Mazur L, Opydo-Chanek M, Łukawska M and Oszczapowicz I: In vitro induction of apoptosis and necrosis by new derivatives of daunorubicin. Anticancer Res 33: 4439-4444, 2013.

15 Stojak M, Łukawska M, Oszczapowicz I, Opydo-Chanek M and Mazur L: Cell-cycle disturbance and induction of programmed death by new formamidine analogs of daunorubicin. Anticancer Res 43: 7151-7158, 2014.

16 Opydo-Chanek M, Rak A, Cierniak A and Mazur L: Combination of ABT-737 and resveratrol enhances DNA damage and apoptosis in human T-cell acute lymphoblastic leukemia MOLT-4 cells. Toxicol In Vitro 42: 38-46, 2017.

17 Henriquez M, Armisen R, Stutzin A and Quest AFG: Cell death by necrosis, a regulated way to go. Curr Mol Med 8: 187-206, 2008.

18 Galluzzi L, Bravo-San Pedro JM, Vitale I, Aaronson SA, Abrams JM, Adam D, Alnemri ES, Altucci L, Andrews D, AnnicchiaricoPetruzzelli M, Baehrecke EH, Bazan NG, Bertrand MJ, Bianchi K, Blagosklonny MV, Blomgren K, Borner C, Bredesen DE, Brenner C, Campanella M, Candi E, Cecconi F, Chan FK, Chandel NS, Cheng EH, Chipuk JE, Cidlowski JA, Ciechanover A, Dawson TM, Dawson VL, De Laurenzi V, De Maria R, Debatin K-M, Di Daniele N, Dixit VM, Dynlacht BD, El-Deiry WS, Fimia GM, Flavell RA, Fulda S, Garrido C, Gougeon M-L, Green DR, Gronemeyer H, Hajnoczky G, Hardwick JM, Hengartner MO,
Ichijo H, Joseph B, Jost PJ, Kaufmann T, Kepp O, Klionsky DJ, Knight RA, Kumar S, Lemasters JJ, Levine B, Linkermann A, Lipton SA, Lockshin RA, López-Otín C, Luglli E, Madeo F, Malorni W, Marine J-C, Martin SJ, Martinou J-C, Medema JP, Meier P, Melino S, Mizuhima N, Moll U, Muñouz-Pinedo C, Nuñez G, Oberst A, Panaretakis T, Penninger JM, Peter ME, Piacentini M, Pinton P, Prehn JH, Puthalakath H, Rabinovich GA, Ravichandran KS, Rizzuto R, Rodrigues CM, Rubinsztein DC, Rudel T, Shi Y, Simon H-U, Stockwell BR, Szabadkai G, Tait SW, Tang HL, Tavernarakis N, Tsujimoto Y, Vanden Berghe T, Vandenabeele P, Villunger A, Wagner EF, Walczak H, White E, Wood WG, Yuan J, Zakeri Z, Zhivotovsy B, Melino G and Kroemer G: Essential versus accessory aspects of cell death: recommendations of the NCCD. Cell Death Differ 22: 58-73, 2015.

19 Kroemer G, Galluzzi L, Vandenabeele P, Abrams J, Alnemri ES, Baehrecke EH, Blagosklonny MV, El-Deiry WS, Golstein P, Green DR, Hengartner M, Knight RA, Kumar S, Lipton SA, Malorni W, Nuñez G, Peter ME, Tschopp J, Yuan J, Piacentini M, Zhivotovsky B and Melino G: Classification of cell death: recommendations of the Nomenclature Committee on Cell Death 2009. Cell Death Differ 16: 3-11, 2009.

20 Galluzzi L, Vitale I, Abrams JM, Alnemri ES, Baehrecke EH, Blagosklonny MV, Dawson TM, Dawson VL, El-Deiry WS, Fulda S, Gottlieb E, Green DR, Hengartner MO, Kepp O, Knight RA, Kumar S, Lipton SA, Lu X, Madeo F, Malorni W, Mehlen P, Nuñez G, Peter ME, Piacentini M, Rubinsztein DC, Shi Y, Simon H-U, Vandenabeele P, White E, Yuan J, Zhivotovsky B, Melino G and Kroemer G: Molecular definitions of cell death subroutines: recommendations of the Nomenclature Committee on Cell Death. Cell Death Differ 19: 107-120, 2012.

21 Mazur L: Induction of apoptosis and necrosis of hematopoietic cells by thiols, ionizing radiation, and chemotherapeutic agents. Jagiellonian University, Kraków, pp. 1-120, 2002 (in Polish).

22 Ziegler U and Groscurth P: Morphological features of cell death. Physiology 19: 124-128, 2004.

23 Kroemer G, El-Deiry WS, Golstein P, Peter ME, Vaux D, Vandenabeele P, Zhivotovsky B, Blagosklonny MV, Malorni W, Knight RA, Piacentini M, Nagata S and Melino G: Classification of cell death: recommendations of the Nomenclature Committee on cell Death. Cell Death Differ 12: 1463-1467, 2005.

24 Denecker G, Vercammen D, Declercq W and Vandenabeele P: Apoptotic and necrotic cell death induced by death domain receptors. Cell Mol Life Sci 58: 356-370, 2001.

25 Denecker G, Vercammen D, Steemans M, Van den Berghe T, Brouckaert G, Van Loo G, Zhivotovsky B, Fiers W, Grooten J, Declercq W and Vandenabeele P: Death receptor-induced apoptotic and necrotic cell death: differential role of caspases and mitochondria. Cell Death Differ 8: 829-840, 2001.

26 Nunez G, Benedict MA, Hu Y and Inohara M: Caspases: the proteases of apoptotic pathway. Oncogene 17: 3237-3245, 1998.

$27 \mathrm{Li} \mathrm{J}$ and Yuan J: Caspases in apoptosis and beyond. Oncogene 27: 6194-6206, 2008.

28 Gotlieb RA: Mitochondria: execution central. FEBS Lett 482: 6$12,2000$.

29 Tsuimoto Y: Apoptosis and necrosis: intracellular ATP level as a determinant for cell death modes. Cell Death Differ 4: 429-434, 1997.

30 Kroemer G, Dallaporta B and Resche-Rigon M: The mitochondrial death/life regulator in apoptosis and necrosis. Annu Rev Physiol 60: 619-642, 1998. 
31 Lee $\mathrm{HC}$ and Wei H: Mitochondrial role in life and death of the cell. J Biomed Sci 7: 2-15, 2000.

32 Arciuch VGA, Alguero ME, Poderoso JJ and Carreras MC: Mitochondrial regulation of cell cycle and proliferation. Antioxid Redox Signal 16: 1150-1180, 2012.

33 Robertson JD, Orrenius S and Zhivotovsky B: Review: Nuclear events in apoptosis. J Struct Biol 129: 346-358, 2000.

34 Halestrap AP, Doran E, Gillespie JP and Oyule A: Mitochondria and cell death. Biochem Soc Trans 28: 170-177, 2001.

35 Surova $O$ and Zhivotovsky B: Various modes of cell death induced by DNA damage. Oncogene 32: 3789-3797, 2013.
36 Murname JP: Cell cycle regulation in response to DNA damage in mammalian cells: A historical perspective. Cancer Metast Rev 14: 17-29, 1995.

37 Szuławska, A and Czyż M: Molecular mechanisms of anthracyclines action. Postępy Hig Med Dośw 60: 78-100, 2006 (in Polish).

Received August 19, 2017 Revised September 25, 2017 Accepted October 9, 2017 